\title{
Conflict Between Hizb Ut-Tahrir And Islamic Civil Society In Indonesia:A Countermovement Approach
}

\author{
Hasbi Aswar \\ Department of Political Science, Kulliyah of Islamic Revealed Knowledge and Human \\ Sciences, International Islamic University of Malaysia, Jalan Gombak, 53100, Selangor, \\ Malaysia \\ E-mail: hasbiaswar@uii.ac.id \\ Danial Bin Mohd. Yusof \\ International Institute of Islamic Thought and Civilization, International Islamic \\ University of Malaysia. Persiaran Tuanku Syed Sirajuddin, Bukit Tunku, 50480 Kuala \\ Lumpur, Wilayah Persekutuan Kuala Lumpur, Malaysia \\ E-mail: danialmy@iium.edu.my \\ Rohana Binti Abdul Hamid \\ Department of Political Science, Kulliyah of Islamic Revealed Knowledge and Human \\ Sciences, International Islamic University of Malaysia, Jalan Gombak, 53100, Selangor, \\ Malaysia \\ E-mail: rohanahamid@iium.edu.my
}

\begin{abstract}
In a social movement study, countermovement emerges when certain movement is considered to bring threat to the status quo or the current political and social condition. Social movement seeks for changing the existing situation while the countermovement pursues to keep it. As a result, the conflict between two becomes inevitable, where both will compete to win over the other. The existence of Hizb ut-Tahrir in Indonesia (HTI) for years is responded by some Islamic groups especially Nahdlatul Ulama (NU) and its allies, as threat to the Indonesian life due to the idea brought by HTI. It becomes the root of conflict between HTI and other Islamic groups in Indonesia. This article aims to explain the conflict between HTI and other Islamic groups by elaborating the effort of the Islamic groups to counter the HTI narratives and mobilization by using countermovement approach in social movement studies. This article is a case study research and using mainly secondary data to analyze the issue. This article found that Nahdlatul Ulama as the main countermovement played significant role to counter Hizb ut-Tahrir's religious and political narratives as well as its political mobilization.
\end{abstract}

Keywords: Countermovement; Hizb ut-Tahrir Indonesia; Nahdlatul Ulama;

Social Movement

Abstrak
Dalam studi gerakan sosial, countermovement atau gerakan tandingan muncul
ketika sebuah gerakan tertentu dianggap membawa ancaman terhadap
kemapanan politik dan sosial. Sebuah gerakan sosial berusaha untuk mengubah 
situasi yang ada sementara gerakan tandingan akan berusaha untuk mempertahankannya. Akibatnya, konflik antara keduanya menjadi tak terelakkan, di mana keduanya akan bersaing untuk memenangkan satu sama lain. Keberadaan Hizbut Tahrir di Indonesia (HTI) selama bertahun-tahun direspon oleh beberapa kelompok Islam terutama Nahdlatul Ulama (NU) dan sekutunya, sebagai ancaman terhadap Indonesia karena ide yang dibawa oleh HTI. Ini kemudian menjadi akar konflik antara HTI dan kelompok Islam yang lain di Indonesia. Artikel ini bertujuan untuk menjelaskan konflik antara HTI dan kelompok-kelompok Islam lainnya dengan menguraikan upaya kelompokkelompok Islam untuk melawan narasi dan mobilisasi HTI dengan menggunakan konsep countermovement dalam studi gerakan sosial. Artikel ini menggunakan metode penelitian studi kasus dalam penelitian kualitatif serta menggunakan data sekunder untuk menganalisis masalah ini. Artikel ini menemukan bahwa Nahdlatul Ulama, sebagai pemeran utama gerakan kontra, memainkan peran penting untuk melawan narasi keagamaan dan politik Hizbut Tahrir serta mobilisasi politiknya.

Kata Kunci: Countermovement; Gerakan Sosial; Hizbut Tahrir Indonesia;

Nahdlatul Ulama.

\section{A. Introduction}

In a phenomenon of social movements, when a movement is considered to pose a threat to existing social or political conditions, other movements will emerge to respond or oppose it or there will be a response from the state to either suppress or facilitate the movement. If the movement is welcomed by the state, there will be no conflict between the state and the movement. In contrast, if the state suppresses the movement, then a conflict between the two actors will occur, where there will be competition to win the political competition. Social movements will struggle to change and the state will resist and resist the influence of movements. The state will try to kill the movement; on the other hand, the movement will look for ways to stay alive until the goal is reached.

Hizb ut-Tahrir is an Islamic movement that has gone through this kind of conflict between states and countermovement. As a global movement, which advocates for revolutionary change from the current modern state system, the Hizb ut-Tahrir is largely rejected by Muslim-majority countries, in West Asia, Central Asia, and North Africa. In western countries, HT is often depicted in negative images such as radical groups and fundamentalists although it is not 
prohibited. This article attempts to discuss the relation between HTI and its countermovement by explaining the countermovement's counternarratives and countermobilization to hizb ut-tahrir Indonesia.

\section{B. Research Method}

This article uses the case study method in the social science research method by taking a social movement issue with specifying on countermovement approach. This approach will be applied to describe the response of Islamic civil society on the existence of Hizb ut-Tahrir in Indonesia (HTI). Nahdlatul Ulama is put here as the countermovement to HTI. To collect the data for this research article, secondary data is mostly used through the website, such as NU Online and other relevant websites, journal articles are also used that is relevant to this topic. All the collected data will be analyzed by classifying them based on the approach used in this article.

\section{Result and Discussion}

\section{Countermovement in The Social Movement Studies}

Countermovement emerges in social movement for two reasons: because of the actions of other movements or because of the degree of success of other movements. Therefore, the rise of countermovement is the result of other movement activities. This, for example, occurs in the process of mobilizing certain movements to advocate for certain problems in society, which are often not accepted by all people or populations. Some people may think or realize that the social movement challenges positions, traditions, culture, and practices that are widely accepted in society ${ }^{1}$. This awareness raises a motivation to counter the existing movement. The more increased movement in mobilization; the countering process will also increase.The definition of a countermovement according to the dictionary of sociology is an "organized response to a social

\footnotetext{
${ }^{1}$ Banaszak dan Heather 2010, "Explaining Movement and Countermovement Events in the Contemporary U.S. Women's Movement," in the American Political Science Association Meetings, https://doi.org/http://dx.doi.org/10.2139/ssrn.1668884.
} 
movement, with the purpose of blocking the movement's activities, resisting change, and presenting alternative points of view. Counter-movements may be spontaneous expressions of public feeling, or fronts for interest groups" (oxfordreference.com)". In a short definition, Turner and Killian define that countermovement as a movement mobilized against other social movements ${ }^{2}$.

The relationship between movement and countermovement is in a conflict relationship, where both compete to persuade people or authorities to support and follow their arguments. Moreover, social movements and countermovements imitate each other in their actions or strategies. In fact, sometimes both try to defeat each other. The existence of a countermovement is an obstacle in gaining the success of social movements. But if a countermovement act with violence, then it can also motivate social movements to become more radical ${ }^{3}$.

There are several forms of interaction between movement and countermovement according to Zald and Useem (1983). First, they could meet and debate in any place even on the road or public space or during a demonstration. They could also meet and debate in a formal forum such as debates on university campuses, TV, radio and so on. Second, Movement and countermovement compete in an effort to influence the same third parties like influencing the public, and the government. Third, Movement and countermovement, both compete to disrupt the effects of each other to make the movement ineffective or even dead ${ }^{4}$. In Indonesia, Nahdlatul Ulama together with its under bow groups Banser and GP Ansor are the countermovement groups on HTI. NU has been long time to disagree with the idea of HTI but only under the regime of Joko Widodo especially in 2017, NU and its allies openly show their opposition and countering HT movement in Indonesia. The government also supports the countermovement activities of NU. The countermovement approach

\footnotetext{
${ }^{2}$ Lo 1982, "Countermovements and Conservative Movements in the Contemporary U.S., ” Annual Review of Sociology 8, no. 1 (1982): h. 107-34, https://doi.org/10.1146/ annurev.so.08.080182.000543.

${ }^{3}$ Della Porta dan Diani 2006, Social Movements: An Introduction, Second Edi Blackwell Publishing, Oxford.

${ }^{4}$ Zald dan Useem 1982, "Movement and countermovement: Loosely coupled conflict,"
} 
will be used to discuss the reason of NU to counter HT and the strategies used by NU to counter HTI in Indonesia.

\section{Hizb ut-Tahrir Indonesia}

Hizb ut-Tahrir (the liberation party) was founded by Sheikh Taqiyuddin an-Nabahani (1909-1977), an Islamic scholar and judge. This party was first founded in Jordan and officially registered with the Jordanian government in 1953, and later spread regionally in Arab countries and then entered over 40 countries with about millions of members worldwide ${ }^{5}$.

Hizb ut-Tahrir (HT) as an Islamic political party aims to turn the present democratic structure in the Muslim world from a secular system to an Islamic one. HT claims that the root cause of the modern state, particularly in the Muslim world, is the acceptance of secular structures in social, economic and political life, such as democracy, liberalism and human rights. According to HTI, Muslims need to change the current system into an Islamic political system, which applies all aspects of Islamic law to solve all Muslim problems. HT argues that the only system recognized in Islam is the Khilafah system, which Prophet Muhammad and his companions inherited ${ }^{6}$.

To transform the secular structure, HT insisted, one must adopt the prophet's strategy of religious transformation: through intellectual and religious action, without resorting to violence. Based on the interpretation of the prophet method, HT concluded that there are three steps to change the political condition, first, the process of culturing, second, to engage with people in winning their hearts and minds, as well as cutting loyalty to the state and political system. Thirdly, creating a state in which applies Islamic sharia law ${ }^{7}$. HT's hostility to the secular political system and the call for Islamic rule and the Islamic State are the

\footnotetext{
5 Shiv Malik, "For Allah and the Caliphate," newstateman, 2004, https://www.newstatesman.com/node/195114, Accessed 20 Maret 2019; Muhammad Muhsin Rodhi, Tsaqofah Dan Metode Hizbut Tahrir Dalam Mendirikan Negara Khilafah 2012, Al Azhar Freshzone Publishing, Bogor.

${ }^{6}$ Hizb ut-Tahrir 2005, The Institutions of State, Al-Khilafah Publications, London.

${ }^{7}$ Hizb ut-Tahrir 1999, The Methodology of Hizb ut-Tahrir for Change, Al-Khilafah Publications, London.
} 
key narratives of this group. Consequently, It became controversial among Muslims, where many chose to support it group, and others criticized and opposed that group as well. In terms of the state's response to HT, this group has experienced various kinds of state oppression, including detention, murder and stigma in many countries, especially in Muslim and Arab countries ${ }^{8}$.

In the 1980s, HT started work in Indonesia and introduced by Abdurrahman al-Baghdadi. Throughout the 1980s and 1990s, Hizb ut-Tahrir activists worked mainly through Islamic student organizations throughout Indonesian universities, and then expanded broader in the Indonesian community. HT publicly announced its work and ideas in Indonesia in 2000 with the organizing of the first International Khilafah Conference, attended by around 2000 people. It was then followed by extensive interaction with the people of Indonesia through various events and programs including media publication, talk shows, demonstrations, and international conferences. All of these activities are instruments for Hizb ut-Tahrir to communicate its Islamic and political ideas in Indonesian people 9 .

\section{Countering Hizb ut-Tahrir Narratives and Mobilization}

Hizb ut-Tahrir (HTI) has emerged in Indonesia for about more than twenty years, since 1980s but it worked underground until 2000s after Indonesian totalitarian regime, Soeharto stepped down. Since then HTI worked openly in propagating its ideology through many tactics and strategies such as producing leaflets, books, magazines; conducting seminars, conferences, public discussions; visiting prominent religious and political figures; attending government`s events; carrying out mass demonstration and cooperating with other Islamic groups in Indonesia.

Since 2000s, Hizb ut-tahrir has become a very active Islamic organization in Indonesia and impact to the increase of the members and its sympathizers from

8 Aswar 2017, What is Wrong with Democracy? A View from Hizbut Tahrir," Transformasi Global 4, no. 1, 2017

${ }^{9}$ Muhtadi 2009, "The Quest for Hizbut Tahrir in Indonesia," Asian Journal of Social Science 37, no. 4, 2009: 623-45; Yusanto 2013, "Capaian Muktamar Khilafah 2013," hizbIndonesia, 2013. Accessed 30 July 2019 
all level of society: students, teachers, lecturers, businessman, peasants and so on. Unfortunately there is no exact number of HTI members in Indonesia due to unwillingness of HTI leaders to reveal it. Some researchers only can estimate around ten thousands to one million members 10 .

The mobilization of Hizb ut-tahrir in Indonesia, and its objective to reestablish khilafah state have started again the discussion on the importance of this state in today`s world. Different responses have come from many Islamic groups, and scholar on HTIs political agendas. Some groups agreed with HTI including Islamic defender front (Front Pembela Islam, FPI), Majelis Mujahidin Indonesia (Council of Mujahiddin Indonesia, MMI), but others opposed like Nahdlatul Ulama and Muhammadiah, the two biggest Islamic organizations in Indonesia.

For Islamic Defender Front (FPI) and MMI, even though have the same dream of khilafah, both perceived differently on how to struggle for it. For FPI, its focus in the implementation of sharia in Indonesia is through gradual implementation.

FPI believes that by supporting pro Islamist political candidates, Islamic laws / sharia can be implemented in Indonesia. Moreover the movement also involved in cooperation with the government: in the fields of social humanity, post-disaster relief, and social development. FPI also is well known as violence group for some of its action to perform what is called amar ma`ruf nahi munkar, enjoining good, and forbidding evil. It then made this movement become controversial in Indonesia.

On the other hand, Majelis Mujahidin Indonesia (MMI) eventhough it has the same rhetoric with HT on khilafah and stance on democracy. MMI narratives on Islamic state focuses on the Indonesian level, not transnational like HTI does. Moreover, the idea of establishing sharia is not manifested in every issues advocated by MMI, or in its collective actions. Different with HTI that links every

${ }^{10}$ Greg Fealy 2007, “Hizbut Tahrir in Indonesia: Seeking A Total Islamic Identity," in Islam and Political Violence: Muslim Diaspora and Radicalism in the West, ed. oleh Shahram Akbarzadeh dan Fethi Mansouri, Tauris Academic Studies, New York, h. 151-164. 
issues on the need for establishing and implementing Islamic state or sharia ${ }^{11}$. Whereas Muhammadiah and Nadhlatul Ulama, both disagree with the idea of sharia and khilafah of Hizb ut-Tahrir. Muhammadiah argued that Indonesia that exists today with its ideology and constitution are final form of Indonesia. From the Islamic point of view, Indonesia is not an Islamic state but it has been conformed to Islamic values. According to Muhammadiah, the main goal of muhammadiah`s work is to create the true picture of Islam through cultural approach not structural or political approach, that is why Muhammadiah does not have any idea to establish a sharia state or khilafah ${ }^{12}$. Haedar Nashir, the current leader of Muhammadiah, statet that there is no place in Muhammadiah for those who have an ideology that against pancasila including khilafah, communism, and secularism ${ }^{13}$.

According to Din Syamsuddin, Khilafah is actually an important part of Islam that based on al-Quran and hadith but it does not necessarily mean that Islam has its own particular state. That is why; there is no obligation to establish an Islamic state for Muslim. Khilafah according to Syamsuddin is a symbol of unity, solidarity of Islam regardless the differences of language, and culture. Hence, the need for khilafah according to Din is khilafah as civilization not as a structure of state ${ }^{14}$. Afterall, For Muhammadiah Indonesia is a state of consensus and witness ( dar al-'ahdi wa al-syahadah) that means that Indonesia was established through national consensus from all element of Indonesian societies and place of witness toward a state of peace, tranquility, developed, prosperity under the god almighty`s protection ridha Allah swt. This principles, is said, are in line with the Islamic ideals of state to be "Baldatun thayyibatun wa rabbun ghafur", a good state that is under the blessing of the god almighty. In doing that,

${ }^{11}$ Lajnah Tanfidziyah Majelis Mujahidin 2014, Lajnah Tanfidziyah Majelis Mujahidin 2014,, Accessed 12 November 2019.

${ }^{12}$ Muhammadiah 2018,Muhammadiah 2018, Accessed 19 November 2019.

${ }^{13}$ Muhammadiah 2019, "Haedar: Muhammadiyah Berpaham Negara Pancasila Darul Ahdi Wasyahadah - Berita | Muhammadiyah," muhammadiah, 2019., Accessed 19 November 2019.

${ }^{14}$ Muhammadiah 2017, "Din Syamsuddin: Khilafah Tidak Diabaikan dan Pancasila Tetap Ditegakkan, Begini Solusinya - Berita | Muhammadiyah,” muhammadiah, 2017., Accessed 19 November 2019. 
the people of state should believe and pray to god, not committing crimes, perform good relation with God and other human being, and treated others equally, also always struggle to keep the status as the best ummah (khayra ummah) ${ }^{15}$.

However, in encountering the emergence of Islamic transnationalism in Indonesia Muhammadiyah propose to address it through comprehensive and peaceful approach. Muhammadiyah argues that Islamic method that is adopted is a peaceful and comprehensive method in addressing many social problems in the Muslim live. Islamic radicalism is only one issue but to solve that must be through considering many variables not only religion but also social, political and economic issues. Muhammadiyah also rejects to only denote radicalism to Muslim because radicalism can arise from all ideologies, cultures, and beliefs.

In solving radicalism issue, Muhammadiyah contends, the approach should be based on law and soft approach that means, to carry out dialogue and integrate the extremists in the society. In contrast, using hard approach to the extremist and countering the radical narratives carelessly even can contribute to rise of Muslim opposition toward state and even can contribute to radicalize Muslim more than before. This narrative, that then makes Muhammadiyah very critical to the government's policies on counter-terror and counter-radicalism agendas.

Nahdlatul Ulama (NU), on the other side, is very much more serious to respond the coming of transnational Islamic groups in Indonesia including HT, Salafism, Muslim Brotherhood, and jihadist groups. NU believes that those foreign Islamic groups can only bring threat and disaster to Indonesia because of their ideas and vision that against Islamic tradition in Indonesia.

According to Nahdlatul Ulama, Indonesian Islam is a uniqe form Islam comparing to the Islamic traditions in the Middle East. Indonesian Islam is the picture of the real Islam that is peaceful, tolerant, and inclusive. Also, Islam in Indonesia accepts the current form of Indonesian political structure: nationalism

${ }^{15}$ Pimpinan Pusat Muhammadiah 2015, Negara Pancasila Sebagai Darul Ahdi Wa Syahadah, Pimpinan Pusat Muhammadiah, Makassar 
and democracy. Most importantly, Islam in Indonesia was spread through word not sword like in the Middle East. Nahdlatul Ulama contended that this unique form of Islam in Indonesia is called as Islam Nusantara. Whereas the face of Islam in the Middle East is very negative, conflict, authoritarianism, dictatorship, exclusive and intolerant.

Hence, if now in Indonesia there is an increasing phenomenon of transnational Islamic movements from notably the Middle Eastern countries, it means danger to Indonesian Islam. Those groups bring their Islamic traditions that contrasted with Indonesian tradition. As a result, there should be no place for them to be free in disseminating their ideas and thought.

Regarding the relation with Islam and the state, the leaders of Nahdlatul Ulama have discussed it clearly that Islam has no a complete concept of state format let alone to obligate its adherents to pursue it. This political and religious stance has made NU being able to compromise with any regime. Since founded in 1925 this group, under the control of Dutch colonial regime, and under Japan control NU admitted the two regimes, even under Japan, NU leader was appointed to be the leader of religious affairs (Shumubu). For NU, the colonial regimes, Dutch or Japan, are legal and accepted regimes, and it does not change the status of Indonesia as Darul Islam (Islamic state), considering that there were many Islamic sultanates or kingdoms and as long as Islam is still easily practiced by Muslim. Moreover, Muslim should defend the state whoever the regimes are ${ }^{16}$.

After Indonesian independence, 1945, NU also showed its political and religious position that supports the newborn state. Soekarno as the first president was granted religious title as "ulil-amri dharuri bis saukah" that means religiously accepted as Indonesian leader. Cooperative engagement with regimes then was still upholded by NU under new order (order baru), Soeharto and until today.

According to Abdurrahman Wahid, (1940-2009), the chairman of Nahdlatul Ulama (1991-1999), Islam never taught to establish a particular state, or

${ }^{16}$ Aswar 2015, “Organisasi Nadhlatul Ulama Memerangi Radikalisme Politik Islam di Indonesia” Universitas Islam Indonesia. 
an Islamic state system. For him, the establishment of an Islamic state would only make non-Muslims citizens as second-class citizens who would be eliminated including the non-religious Muslim. Wahid contended that Muslims need only to make Islam a part of the practice of daily life such as embrace tauhid, practice of Islamic sharia, help fellow human beings, professionals in work, including being patient in every disaster and test that occur. If all of the above values have been implemented, according to Wahid, the Islamic system is no longer needed; even to measure the level of Muslim`s piety or obedience to god is not by the realization of an Islamic system or state ${ }^{17}$.

Moreover, in Wahid's view, the history of Islam proves there was no single system that was monolithic, such as the absent of the single method of appointment of caliph (leader) from Abu Bakr to Umar bin Khattab, to Uthman ibn Affan and to Ali ibn Abi Talib and later rulers afterwards. Likewise, the size of Islamic societies is diverse from time to time. In the era of the Prophet Muhammad and Abu Bakr, the Islamic community took the form of a community, then turned into an empire in the era of Umar, and nation state in the era of colonialism. This diversity, according to Wahid, made the concept of an Islamic state unable to be developed ${ }^{18}$. Therefore, According to Wahid, in the view of Islam there is no requirement for an Islamic system, which means that there is no obligation to establish an Islamic state ${ }^{19}$.

This argument was also similar with, Hasyim Muzadi, the chairman of PBNU 1999-2010. Muzadi argued, the ideology of the pro- Khilafah activists clearly threatened the unity of Republic of Indonesia, Pancasila and the Constitution because this idea did not originate from the traditions and culture of Indonesian society. These activists can only disturb the peace of the state because it only invites de-legitimation and deconstruction of an established and sovereign

\footnotetext{
${ }^{17}$ Wahid 2011, Islamku, Islam Anda, Islam Kita : Agama Masyarakat Negara Demokrasi, Digital Edition, Democracy Project, Jakarta.

${ }^{18}$ Wahid 2011, op cit

${ }^{19}$ Wahid 2011, op cit
} 
state ${ }^{20}$. Muzadi considered that there was a misinterpretation of the pro-Khilafah activists regarding the understanding of complete Islam (Islam kaffah). The prokhilafah movement believes that Islam Kaffah means that it must establish an Islamic government whereas, according to Muzadi, Islam kaffah is indeed mandatory but not unnecessary through Islamic government. "To truly Islam does not have to be with the Khilafah Islamiyah. Recognizing and obeying a legitimate and sovereign government is mandatory" 21.

Said Aqil Siradj, Chairman of PBNU (2010-now) has also the same opinion that the idea of the Khilafah which is international is illogical and rational because historically the Prophet never established an Islamic state; instead, the Prophet made the Medina charter as an agreement on which the legal basis governing relations between citizens of different ethnicities, races and his religion so that he can live in harmony and harmony. After the death of the prophet was not found a standard model of government, Muslims have been led in the khilafah system, the Emirate and even the sultanates whose numbers are quite large and mostly, according to Siradj, in an Islamic government where there has been a lot of bloodshed among Muslims themselves. So what is more important according to Siradj is that the leader is honest, fair, and serves the community well ${ }^{22}$.

Other criticism on the idea of Khilafah came from Idrus Ramli23, Ainur Rofiq al-Amin ${ }^{24}$, and Nadirsyah Hosen ${ }^{25}$. Idrus Ramli specifically wrote two books related to Hizb ut-Tahrir namely "Hizb ut-Tahrir in the spotlight" or Hizbut Tahrir dalam Sorotan (2011) and "The Effective Way to Silence HTI", Jurus Ampuh Membungkam HTI (2012). In general, those two books mainly rebutted HT`s Islamic narratives and the idea of Khilafah.

${ }^{20}$ Muslimmedianews 2014, "Pandangan KH. Hasyim Muzadi terhadap Gerakan Khilafah," ; NU Online 2007, "Silakan Khilafah, Jangan Bawa Nama NU.," . Accessed 15 December 2015.

${ }^{21}$ NU Online 2007, “PBNU: Konsep Khilafah Islamiyah Tidak Pernah Jelas,”, Accessed 15 December 2015.

${ }^{22}$ NU Online , "PBNU: Khilafah Islamiyah Celakakan Muslim Minoritas di Negara Lain, ” Nu Online, 2007. , Accessed 15 December 2015.

${ }^{23}$ A young scholar of NU, Secretary of the Bahtsul Masail NU in East Java

${ }^{24}$ The head of PCNU magazine in Jombang, east java

${ }^{25}$ Rais Syuriah PCI NU Australia - New Zealand \& Senior lecturer of Monas Law School, Monash University, Australia. 
Idrus Ramli rejects the struggle of the Islamic Khilafah based on several arguments. First, the leadership required by Islam has a general meaning and does not have to be called a khilafah. Secondly, the obligation of Muslims to appoint a single leader who leads all Muslims in the world only applies when Muslims are able to carry it out, if it is not capable then the obligation is null and void. What is obligatory to appoint a single leader if possible is only through ahlul halli wal- 'aqdi and figures that deserve to be leaders of the Ummah, besides these two are not required. So when there is no single leader, only two groups will sin.

Third, citing the opinion of Imam al-Haramain al-Juwaini (1028-1085 $\mathrm{AD}$ ), that scholars do not forbid forming a leadership at the local level if within the scope of global leaders cannot be fulfilled. Fourth, that the era of khilafah was only 30 years old as the hadith of the prophet explained, the khilafah was only 30 years after that was a kingdom (HR Ahmad and al-Tirmidhi). Fifth, when Muslims do not have a caliph, the prophet does not order to fight and participate in upholding a caliph even the prophet invites to stay away from groups that call for division like what has been told in the prophet hadith narrated by al-Bukhari and Muslims 26.

While Ainur Rofiq al-Amin, specifically wrote to analyze critically HTI's ideas on Khilafah in in his doctoral thesis which was published in a book, "Dismantling the Khilafah Project Ala Hizb ut-Tahrir Indonesia", or Membongkar Proyek Khilafah Ala Hizbut Tahrir Indonesia, 2012. He also published some articles, and journals that objected hizb ut-tahrir`s idea. In his book, after discussing critically the arguments of establishing Khilafah and refuting it, Amin concluded, the concept of Khilafah in constructed by HT can turn to be semi absolute - autocratic political system. As a result, it can threaten the Indonesian political live and deny the founding fathers'a ideas and missions that built Indonesian based on diversity, and cultural wisdom 27.

\footnotetext{
${ }^{26}$ Ramli 2013, “Wajibkah Memperjuangkan Khilafah?.," idrusramli, Accessed 15 December 2015.

27 Al-Amin 2012, Membongkar Proyek Khilafah Ala Hizbut Tahrir Indonesia, LKIS Yogyakarta, Yogyakarta
} 
Nadirsyah Hosen, on the other hand, insisted that no single system government in Islam except only government that has general meaning. While the kind of state, I depend on the ijtihad, or ulama`s decision on it. According to Nadirsyah, in Islamic history, there has been varies of state were implemented that called as Khilafah state. Indonesian political system is also the ijtihad of Indonesian ulama, which is also deserved to be denoted as khilafah with its own system and structure. Furthermore, Khilafah is actually the same with other system that has its good and bad side. There are many dark stories in the history of khilafah that same with other systems. Hence, according to Hosen, claiming that khilafah is the single best system is not a good choice ${ }^{28}$.

The response and critics of the idea of Khilafah is very much propagated from Nahdlatul Ulama leaders and members. NU looks very serious to respond this including the rise of HTI influence in Indonesia. Institutionally, the stance of NU on Islam and state and the idea of khilafah were declared in the Musyawarah Nasional Alim Ulama (National Conference of Alim Ulama) held in Jakarta on 12 November 2014, which decided several important points as follows ${ }^{29}$ :

1. Islam as a comprehensive religion (din syamil kamil) cannot possibly miss the problems of the state and government from the discussion agenda. Even though it is not in its full concept, it is in the form of basic values and principles (mabadi hasyyyah). Islam has provided sufficient guidance for its people.

Islam sebagai agama yang komprehensif (din syamil kamil) tidak mungkin melewatkan masalah negara dan pemerintah dari agenda diskusi. Meskipun tidak dalam konsep penuh, itu dalam bentuk nilai-nilai dan prinsip-prinsip dasar (mabadi hasyyyah). Islam telah memberikan panduan yang cukup untuk rakyatnya.

2. Choosing the leader (nashb al-imam) is obligatory, because human life will be chaotic (fawdla / chaos) without a leader. This is confirmed by the statements of the leading scholars, including: a. Hujjat al-Islam Abu Hamid al-Ghazali and Shaykh al-Islam Taqi al-Din Ibn Taimiyyah.

Mengangkat pemimpin (nashb al-imam) adalah wajib, karena kehidupan manusia akan kacau (fawdla / kekacauan) tanpa pemimpin. Ini dikonfirmasi

\footnotetext{
${ }^{28}$ Hosen 2018, Islam Yes Khilafah No, Suka Press, Yogyakarta.

${ }^{29}$ NU Online 2019, "Khilafah dalam Pandangan NU | NU Online"., Accessed 26 November 2019.
} 
oleh pernyataan para ulama terkemuka, termasuk Hujjat al-Islam Abu Hamid al-Ghazali dan Syekh al-Islam Taqi al-Din Ibn Taimiyyah.

3. Islam does not determine let alone oblige a particular form of state and system of government for its adherents. The people are given their own authority to regulate and design government systems in accordance with the demands of the development of the times and places. But most importantly a government must be able to protect and guarantee its citizens to practice and apply the teachings of their religion and be a conducive place for prosperity, welfare, and justice.

Islam tidak menentukan apalagi mewajibkan bentuk negara dan sistem pemerintahan tertentu untuk penganutnya. Rakyat diberi wewenang sendiri untuk mengatur dan merancang sistem pemerintahan sesuai dengan tuntutan perkembangan zaman dan tempat. Tetapi yang paling penting pemerintah harus mampu melindungi dan menjamin warganya untuk mempraktikkan dan menerapkan ajaran agama mereka dan menjadi tempat yang kondusif untuk kemakmuran, kesejahteraan, dan keadilan.

4. Khilafah as a system of government is a historical fact that was once practiced by al-Khulafa al-Rashidun. Al-Khilafah al-rasyidah is a model that is very appropriate to the era; that is, when human life is not under the auspices of nation states (nation states). At that time Muslims were very likely to live in a system of khilafah. When mankind is under the auspices of nation states (nation states), the khilafah system for Muslims worldwide loses its relevance. Even reviving the idea of the Khilafah in our time is a utopia.

Khilafah sebagai sistem pemerintahan adalah fakta sejarah yang pernah dipraktikkan oleh al-Khulafa al-Rashidun. Al-Khilafah al-rasyidah adalah model yang sangat sesuai dengan zaman; yaitu, ketika kehidupan manusia tidak di bawah naungan negara-bangsa (nation state). Pada waktu itu umat Islam sangat mungkin hidup dalam sistem khilafah. Ketika umat manusia berada di bawah naungan negara-bangsa (nation state), sistem khilafah untuk Muslim di seluruh dunia kehilangan relevansinya. Bahkan menghidupkan kembali gagasan Khilafah di zaman kita adalah utopia.

5. The Republic of Indonesia (NKRI) is the result of a noble national agreement among the state founders. This state was formed to accommodate all elements of the nation that are very diverse in terms of ethnicity, language, culture and religion. It is the duty of all elements of the nation to maintain and strengthen the integrity of the Unitary Republic of Indonesia. Therefore, every path and attempt to emerge movements that threaten the integrity of the Republic of Indonesia must be prevented. Because it will cause mafsadah (damage) and divisions of the people. 
Republik Indonesia (NKRI) adalah hasil kesepakatan nasional yang mulia di antara para pendiri negara. Negara ini dibentuk untuk mengakomodasi semua elemen bangsa yang sangat beragam dalam hal etnis, bahasa, budaya dan agama. Adalah tugas semua elemen bangsa untuk memelihara dan memperkuat integritas Negara Kesatuan Republik Indonesia. Karena itu, setiap jalan dan upaya untuk memunculkan gerakan yang mengancam integritas Republik Indonesia harus dicegah. Karena itu akan menimbulkan mafsadah (kerusakan) dan perpecahan rakyat.

6. Muslims should not be trapped in the symbols and formalities of a name that seems Islamic, but must commit to the substance of everything. Thus, fighting for the substantive values of Islamic teachings in a country whatever the name of the country, Islam or not - is far more important than fighting for the upholding of the symbols of the Islamic state.

Muslim tidak boleh terjebak dalam simbol dan formalitas nama yang tampak Islami, tetapi harus berkomitmen pada substansi segalanya. Jadi, memperjuangkan nilai-nilai substantif ajaran Islam di suatu negara - apa pun nama negara itu, Islam atau bukan - jauh lebih penting daripada memperjuangkan penegakan simbol-simbol negara Islam.

Of the many Islamic groups or movements in Indonesia NU apparently is the most serious one to react with the existence of transnational Islamic movements, and its ideas in Indonesia, including HT, Salafism, and Jihadist groups. Comparing to Muhammadiyah as the second largest Islamic group in Indonesia, despite it also objects HT`s idea, countering HT`s idea seems not the part of this group`s main agendas in Indonesia. In Muhammadiyah`s website for example, there is no single article that specifically discuss the idea of khilafah, and to oppose hizb ut-tahrir. Muhammadiyah`s response to HT`s, mostly in the news report of Muhammadiya's activities such as in the welcome speech of its executive leader, Haedar Nashir, Din Syamsuddin ${ }^{30}$. It also can be seen, in Muhammadiyah`s social media accounts, youtube, twitter, facebook and instagram.

In Contrast, for Nahdlatul Ulama, through its medias and activists, not only has very strong opposition to HT, but also very active to counter HT`s ideas. Many books have been published concerning rejection and critic on Hizb ut-

\footnotetext{
${ }^{30}$ http://www.muhammadiyah.or.id/id/search/?s=khilafah
} 
Tahrir including Idrus Ramli`s books, Ainur Rafiq Al-Amin, Nadirsyah Hosen, and Abdurrahman Wahid, 2008. There are also hundreds articles in Nu`s online media, www.nu.or.id, including lectures from Nu`s ulema in YouTube, not to mention other websites that affiliated with NU`s members ${ }^{31}$.

The increase of Banser oppoosition to HTI`s events started in 2016 when HTI organized Muktamar Tokoh Umat (Conference of Ummah Figures) 1437 H. This event was prevented and protested by members of Nahdlatul Ulama and Banser primarily in the region controlled by members of the NU in the eastern part of Java as in Jember, Kediri, Jombang, Magetan, Surabaya, Tulungangung, and Bojonegoro ${ }^{32}$.

Opposition continued in 2017, even becoming massive and national when HTI held another event through a long parade entitled "Masirah Panji Rasulullah" or the Prophet's Flag Parade, which aims to introduce the Prophet Muhammad's flag. The event was held in many provinces and cities in Indonesia from April to May 2017. At the same time, in many places, Banser has also been preparing to mobilize hundreds of its members to block and stop the event. As a result, in many places, security forces canceled HT's events or HTI changed places of the events due to pressure and threats from Banser. Some of the main places where Banser faced HTI were in Semarang (Central Java Province), Bandung (West Java Province), Makassar (South Sulawesi Province), Surabaya (East Java Province), Yogyakarta Province, and Jakarta. Banser actually did not act alone to contain HTI, but also supported and allied with other NU bodies such as youth organizations and NU students such as IPPNU, CBP IPNU, PMII, and GP Ansor.

The culmination of the call and request for anti-HTI Hizb ut-Tahrir was held in June 2017, when around 13 Islamic social organizations allied in the Organization of Friendship Organizations of Islamic Organizations (LPOI Lembaga Persahabatan Ormas Islam) gathered and expressed their support for the

\footnotetext{
${ }^{31} \mathrm{https}: / / \mathrm{www}$. nu.or.id/indeks?d=\&m=\&y=\&cid=\&q=khilafah\&page $=5$

${ }^{32}$ Firdaus 2016, "Pesan GP Ansor: Tak Ada Pemakluman Untuk Hizbut Tahrir," https://www.rappler.com/indonesia/131524-gp-ansor-jombang-hizbut-tahrir; Imam Mubarok, 2016 “Gelar Apel Siaga, Banser Minta Polisi Bubarkan Muktamar HTI Kediri | Merdeka.Com," merdeka.com, https://www.merdeka.com/peristiwa/gelar-apel-siaga-banser-minta-polisi-bubarkanmuktamar-hti-kediri.html, Accessed 09 January 2020.
} 
government to dissolve the Indonesian HIzbut Tahrir. The Thirteen Islamic organizations were Nahdlatul Ulama, Islamic Unity (Persatuan Islam), Al-Irshad Al-Islamiyah, Mathlaul Anwar, Ittihadiyah, Indonesian Chinese Islamic Association (PITI - Persatuan Islam Tionghoa Indonesia), Ikadi, Azzikra, Indonesian Islamic Society, Alwashliyah, Tarbiyah Islamiyah Association, Islamic Union (UMI), UMI and HBMI 33.

Demands to dissolve Hizb ut-Tahrir and opposition from members of Nahdlatul Ulama in many places in Indonesia were responded to and supported by the government through initiatives to make regulations in lieu of law (Perppu Peraturan Pemerintah Pengganti Undang - Undang). This Perppu is then subsequently used to legitimize the dissolution of Hizb ut-Tahrir Indonesia, by the state. In this point, the countermovement to HTI, particularly Nahdlatul Ulama and its wings win its struggle against Hizb ut-Tahrir Indonesia.

The reason of the state support to the countermovement rathen than to HTI, firstly because of state has the same narrative with the countermovement Islamic groups on the issue of radicalism in Indonesia. Indonesian government has been for a long time working to tackle the issue of radicalism and terrorism in Indonesia $^{34}$.

Responding HTI, according to Mietzner and Fealy, there was a fact that state and NU youth militias cooperated to contain HTI agendas in Indonesia ${ }^{35}$. Furthermore, it was also admitted by HTI’s spokerperson, Ismail Yusanto, who stated that over 20 years, HTI worked in Indonesia but there was no confrontation between HT and other Islamic groups, except in 2016 that according to Yusanto,

${ }^{33}$ Alawi 2017, "Ormas-Ormas Islam Indonesia Dukung Pemerintah Bubarkan HTI," Nu Online, https://www.nu.or.id/post/read/78453/ormas-ormas-islam-indonesia-dukung-pemerin-tahbubarkan-hti-\%0A, Accessed 27 January 2020.

${ }^{34}$ Amir 2020, “An Analysis Of Jokowi 'S Policy In Refusing The Return Of Former ISIS Foreign Terrorist Fighters Indonesia Citizens.” Al-Bayyinah : Jurnal of Islamic Law 4 (1): 11832. https://doi.org/10.35673/al-bayyinah.v3i2.492. h.121

${ }^{35}$ Gregory Fealy, "Jokowi's Bungled Ban of Hizbut Tahrir," Lowy Institute, 2017, https://www.lowyinstitute.org/the-interpreter/jokowi-s-bungled-ban-hizbut-tahrir, Accessed 27 January 2020; Marcus Mietzner, "Fighting Illiberalism with Illiberalism: Islamist Populism and Democratic Deconsolidation in Indonesia, ” Pacific Affairs: 91, no. 2 (2018): h. 277. 
was organized or provoked by the government ${ }^{36}$. Under the administration of President Jokowi since 2014 until the second term 2019, Indonesian government has a close relation with Nadhlatul Ulama mainly in the issue of war against terrorism and radicalism. Nahdlatul Ulama has cooperated with the government agencies such as working with Badan National Penanggulan Terorisme (BNPT), National Counterterrorism Agency, Ministry of Education and Culture, and Ministry of Youth and Sport ${ }^{37}$. Indeed, in 2019, president joko Widodo has chosen Ma`ruf Amin, the supreme leader (Ra`is Aam Syuriah) of Nahdlatul Ulama, as his vice president for the president second term that according to many observers was merely strategy to contain the influence of radical muslim influence in politics during the presidential campaign and election ${ }^{38}$.

\section{Conclusion}

A social movement that pursues for social and political change will always face an opposition from other groups or countermovement including state. As a result, conflict between social movement and countermovement becomes inevitable. The two actors will always be in conflict until one loses and other wins the conflict.

The conflict between HTI and the Islamic movement in Indonesia is an example of conflict between social movement and its countermovement. HTI works in Indonesian based on beliefs that Indonesia should transform from the current political system to Islamic political Islam. It becomes the main narrative of HT`s propagation in Indonesian society. On the other hand, Nahdlatul Ulama and its wings such as Banser and Anshor act as countermovement to HTI. In countering HTI political activities NU and its wings, counter the narratives of HTI and delegitimized the idea of khilafah adopted and propagated by HTI. On the

\footnotetext{
${ }^{36}$ Hizb-Indonesia 2017, "Ustadz Ismail Yusanto: Dakwah Kok Dituduh Makar?," hizbIndonesia.info, 2017, http://hizb-indonesia.info/2017/05/02/ustadz-ismail-yusanto-dakwah-kokdituduh-makar/, Accessed 16 February 2020.

37 Aswar 2016, "Respon Nahdlatul Ulama Terhadap Gagasan Islam Radikal Di Indonesia," Thaqafiyyat 17, no. 1 (2016): h.14.

${ }^{38}$ Greg Fealy 2018, "Ma'ruf Amin: Jokowi's Islamic Defender or Deadweight?," https://www.newmandala.org/maruf-amin-jokowis-islamic-defender-deadweight/., Accessed 17 July 2020.
} 
other hand, in 2016, these countermovements increase its countermobilization by stopping and disturbing HTI agenda in many places in Indonesia. Due to the active and massive counter to HTI, the countermovements, got supports from the state that decided to dissolve HTI with the security reason.

\section{References:}

Al-Amin, Ainur Rofiq. 2012. Membongkar Proyek Khilafah Ala Hizbut Tahrir Indonesia. Yogyakarta: LKIS Yogyakarta.

Alawi, Abdullah. 2017. "Ormas-Ormas Islam Indonesia Dukung Pemerintah Bubarkan HTI." Nu Online. 2017.

Amir, Irfan. 2020. "An Analysis Of Jokowi' S Policy In Refusing The Return Of Former ISIS Foreign Terrorist Fighters Indonesia Citizens." Al-Bayyinah: Jurnal of Islamic Law 4 (1): 118-32. https://doi.org/10.35673/albayyinah.v3i2.492.

Aswar, Hasbi. 2015. "Organisasi Nadhlatul Ulama Memerangi Radikalisme Politik Islam di Indonesia." Universitas Islam Indonesia.

—. 2016. "Respon Nahdlatul Ulama Terhadap Gagasan Islam Radikal di Indonesia." Thaqafiyyat 17 (1): 2-17.

- 2017. "What is Wrong with Democracy? A View from Hizbut Tahrir." Transformasi Global 4 (1).

Banaszak, Lee Ann, dan Ondercin Heather. 2010. "Explaining Movement and Countermovement Events in the Contemporary U.S. Women's Movement." In the American Political Science Association Meetings. Washington DC. https://doi.org/http://dx.doi.org/10.2139/ssrn.1668884.

Fealy, Greg. 2007. "Hizbut Tahrir in Indonesia: Seeking A Total Islamic Identity." In Islam and Political Violence: Muslim Diaspora and Radicalism in the West, diedit oleh Shahram Akbarzadeh dan Fethi Mansouri, 151-64. New York: Tauris Academic Studies.

_. 2018. "Ma'ruf Amin: Jokowi's Islamic defender or deadweight?" 2018.

Fealy, Gregory. 2017. "Jokowi’s bungled ban of Hizbut Tahrir." Lowy Institute. 2017.

Firdaus, Febriana. 2016. "Pesan GP Ansor: Tak ada pemakluman untuk Hizbut Tahrir." 2016.

Hizb-Indonesia. 2017. "Ustadz Ismail Yusanto: Dakwah Kok Dituduh Makar?" hizb-Indonesia.info. 2017.

Hizb ut-Tahrir. 1999. The Methodology of Hizb ut-Tahrir for Change. London: Al-Khilafah Publications.

2005. The Institutions of State. London: Al-Khilafah Publications.

Hosen, Nadirsyah. 2018. Islam Yes Khilafah No. Yogyakarta: Suka Press.

Lajnah Tanfidziyah Majelis Mujahidin. 2014. "Pernyataan Majelis Mujahidin:

Daulah Al-Baghdadi (ISIS) Rekayasa Syi'ah Menggunakan Doktrin Khawarij." majelismujahidin. 2014.

Lo, C Y H. 1982. "Countermovements and Conservative Movements in the Contemporary U.S." Annual Review of Sociology 8 (1). Annual Reviews: 107-34. https://doi.org/10.1146/annurev.so.08.080182.000543. 
Malik, Shiv. 2004. "For Allah and the Caliphate." newstateman. 2004.

Mietzner, Marcus. 2018. "Fighting illiberalism with illiberalism: Islamist populism and democratic deconsolidation in Indonesia." Pacific Affairs 91 (2). Pacific Affairs, a division of the University of British Columbia: 261-82. Mubarok, Imam. 2016. "Gelar apel siaga, Banser minta polisi bubarkan Muktamar HTI Kediri | merdeka.com.” merdeka.com. 2016.

Muhammadiah. 2017. "Din Syamsuddin: Khilafah Tidak Diabaikan dan Pancasila Tetap Ditegakkan, Begini Solusinya - Berita | Muhammadiyah.” muhammadiah. 2017.

- 2018. "Safari Ramadhan ke Australia, Yunahar Ilyas Sampaikan Pandangan Ideologi Muhammadiyah - Berita | Muhammadiyah." muhammadiah. 2018.

—. 2019. "Haedar: Muhammadiyah Berpaham Negara Pancasila Darul Ahdi Wasyahadah - Berita | Muhammadiyah." muhammadiah. 2019.

Muhtadi, Burhanuddin. 2009. "The Quest for Hizbut Tahrir in Indonesia." Asian Journal of Social Science 37 (4). Brill: 623-45.

Muslimmedianews. 2014. "Pandangan KH. Hasyim Muzadi terhadap Gerakan Khilafah.” 2014.

NU Online. 2007a. "PBNU: Khilafah Islamiyah Celakakan Muslim Minoritas di Negara Lain.” Nu Online. 2007.

—. 2007b. "PBNU: Konsep Khilafah Islamiyah Tidak Pernah Jelas." Nu Online. 2007.

_. 2007c. "Silakan Khilafah, Jangan Bawa Nama NU.” NU Online. 2007.

_. 2019. "Khilafah dalam Pandangan NU | NU Online." 2019.

Pimpinan Pusat Muhammadiah. 2015. Negara Pancasila Sebagai Darul Ahdi Wa Syahadah. Makassar: Pimpinan Pusat Muhammadiah.

Porta, Donatella Della, dan Mario Diani. 2006. Social Movements: An Introduction. Second Edi. Oxford: Blackwell Publishing.

Ramli, Muhammad Idrus. 2013. "Wajibkah Memperjuangkan Khilafah?." idrusramli. 2013.

Rodhi, Muhammad Muhsin. 2012. "Tsaqofah dan Metode Hizbut Tahrir dalam Mendirikan Negara Khilafah.” Bogor: al-Azhar Fresh Zone Publishing.

Wahid, Abdurrahman. 2011. Islamku, Islam Anda, Islam Kita: Agama Masyarakat Negara Demokrasi, Digital Edition. Jakarta: Democracy Project.

Yusanto, Ismail. 2013. "Capaian Muktamar Khilafah 2013." hizb-Indonesia. 2013.

Zald, Mayer N, dan Bert Useem. 1982. "Movement and countermovement: Loosely coupled conflict." 